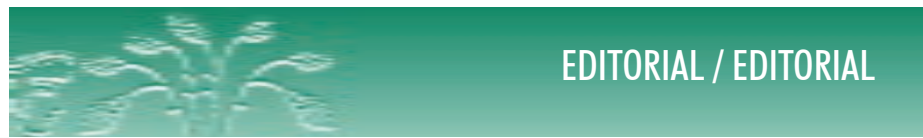

DOI: http://dx.doi.org/10.12957/demetra.2014.12890

\title{
A importância de investir em seções de debates e números temáticos no campo da Alimentação e Nutrição
}

\section{The importance of investing in sections of debates and themed issues in the field of Food and Nutrition}

A partir deste segundo número de 2014, passaremos a contar regularmente com uma Seção de Debates em nossa DEMETRA.

Nossa primeira experiência com esse modelo de publicação aconteceu no ano passado, quando publicamos o primeiro número temático do periódico, então dedicado às Ciências Sociais e Humanas em Alimentação. A dinâmica que seguimos consiste na indicação de um artigo a ser discutido por cerca de três pesquisadores do campo; os autores do texto original dispõem de espaço para uma réplica aos debatedores. Assim, além da publicação de um artigo qualificado, questões de toda ordem em torno dele podem ser levantadas, enriquecendo a abordagem sobre o tema em questão. Trata-se de um espaço muito caro para nós, por corresponder a um lugar de liberdade.

Autores de todos os núcleos de saberes que compõem o campo científico alimentar-nutricional podem ser chamados a esse lugar. É o caso do artigo "Perspectivas do fornecimento de produtos da agricultura familiar para os equipamentos públicos de segurança alimentar e nutricional no Distrito Federal". Ficam aqui nossos agradecimentos às autoras Giselle Silva Garcia e Elisabetta Recine, bem como às docentes Estelamaris Tronco Monego, Silvia do Amaral Rigon e Islandia Bezerra, que aceitaram nosso convite para participar do debate.

Da mesma forma, estamos abertos ao recebimento de propostas de números temáticos que, além da Seção de Debates, poderão contar com algo entre 5 a 15 ou até mais artigos, definidos a partir de amplas chamadas públicas.

Gostaríamos de registrar que seguimos ampliando nossa inserção em bases indexadoras e diretórios de periódicos científicos. Já temos presença em dez desses espaços na Internet e aguardamos respostas de outros mais aos quais solicitamos nossa inclusão. Essas iniciativas conferem maior visibilidade nacional e internacional ao periódico, que se fortalece a cada nova indexação. 
Também é importante assinalar que passamos a publicar o dobro de artigos em relação ao ano passado, tanto pelo aumento da periodicidade - passamos a publicar quatro números por ano, além dos suplementos temáticos - quanto pela elevação no número de artigos publicados em cada fascículo.

Docentes, pesquisadores, estudantes, profissionais: contamos com sua intensa participação! Enviem-nos seus bons trabalhos. Nós os avaliaremos com atenção, cuidado e agilidade.

Sigamos juntos construindo nossa DEMETRA: Alimentação, Nutrição \& Saúde / Food, Nutrition \& Health!

Shirley Donizete Prado

Editora 